\title{
Analyses of floristic composition of the abandoned Cu-dump field Piesky (Staré Hory Mountains, Slovakia)
}

\author{
Ingrid Turisová, Peter Sabo, Tomáš Štrba, Samuel Koróny, Peter Andráš, and Pavel Širka \\ Matej Bel University in Banska Bystrica, 97401 Banská Bystrica, Slovakia \\ Correspondence to: Ingrid Turisová (ingrid.turisova@umb.sk)
}

Received: 12 October 2015 - Revised: 31 March 2016 - Accepted: 3 April 2016 - Published: 20 May 2016

\begin{abstract}
The Cu-dump field Piesky is an important historical abandoned mining area in the region of central Europe, well known for the high content of heavy metals in its soil, especially copper, the content of which varies from 933.40 to $1485.40 \mathrm{mg} \mathrm{kg}^{-1}$. Floristic and phytosociological research was carried out here during the vegetation seasons in 2011-2014. Altogether a total of 156 taxa of vascular plants were found. The most common species were Acetosella vulgaris, Agrostis capillaris, A. stolonifera, Arabidopsis arenosa and Festuca rubra, which were important constituents of all mine heaps in central Slovakia. We examined a total of 11 phytosociological relevés at various sites, which were selected to capture the variability of plant communities throughout topographical and ecological variability, various successional stages and impacts from humans. They were classified into five habitats: initial successional stages, grasslands, forest stands, wetland and feeding grounds for wild animals.
\end{abstract}

Each site was evaluated in terms of its species richness, index of diversity and the representation of metallophytic, alien invasive species, synanthrophytes and native non-apophytes. This representation is based on species number and abundance, and their ratios to all taxa abundance and species richness are reflected by several indicators, which we have called indexes of metallophytization, synanthropization and naturalness of the vegetation (community) composition. In addition, indexes of invasive alien taxa and native non-apophytes proportion were used. Furthermore, each of the 11 sites was characterized by its basic topographic properties and climatic and edaphic variables, using the phytoindication approach based on the Ellenberg indicator values. The correlation analysis has uncovered several important and significant associations between some of these indicators and the climatic and edaphic variables. The negative correlations between the number of native non-apophytes and temperature (and between their relative abundances in the individual habitats and light) partially confirm that on mine heaps the numbers of synanthrophytes retreat into climax forest stands. Other correlations confirm that synanthropisation of the vegetation at a site is also higher in more eutrophic and less acidic soils for mine heaps.

The species richness was highest in the grasslands and wetland and lowest in the initial succession stages, while beta diversity decreased in an opposite direction. Most synanthrophytes were found on grasslands, attracted by higher amount of nutrients in the soil, brought by sewage sludge from water treatment plants during partial recultivation of this mine heap in the years 2000 and 2010. The idea behind it was to support and accelerate the succession, however the use of the sludge may not have been the best option. Despite strict control of its chemical content, a high input of nutrients inevitably increases numbers of synanthrophytes in the vegetation cover. Finally, planting deciduous trees on young mine heaps as a method of directed succession is a better option than planting coniferous ones. The latter trees create acidic litter, increasing heavy metal mobility in the soil. We have found the dump heap Piesky to be a very suitable locality for studying processes of primary and directed succession in extreme environments and their impacts on the floristic composition of vegetation. 


\section{Introduction}

Dump fields, especially mine heaps, represent a specific type of anthropogenic relief - they do not only change the landscape character, but due to an increased content of heavy metals, adversely affect the environment. Specific features of abandoned mine heaps include very sandy, skeletal and dry soil, relatively long exposure to direct sunlight, frequent winds, lack of essential soil nutrients and water as well as increased content of heavy metals. Many of them are listed as environmental loads, needing continuous monitoring of the environmental situation. They create habitats for biota with specific ecological conditions diverging from their surrounding environment, such as a lack or absence of soil layer and nutrients, a high proportion of rock, solifluction, xerothermic microclimatic conditions and an increased (extremely high) content of heavy metals as mentioned above. This causes a slow succession and the development of mostly poor vegetation cover, which has, on the other hand, an important role in protecting unstable slopes against erosion (Conesa et al., 2006). The pioneer tree species that were planted in particular include Betula pendula, Populus tremula, Picea abies, Pinus sp., Salix caprea, Quercus sp. and numerous metallophytes (i.e. metallophilous and metal-tolerant plants).

These taxa are generally described as either metallophilous, i.e. obligatory metallophytes, which are confined to metalliferous soils; metallophytes sensu stricto, which are tolerant to a higher content of heavy metals in soil but do not prefer it, i.e. facultative metallophytes, or as metallophytes sensu lato (Prasad, 2001). In this sense, the plants that grow on mine heaps mostly belong to stress-resistant strategists which dispose of the effective biochemical and physiological defense mechanisms (Emamverdian et al., 2015). These are often externally manifested by reducing growth (Chibuike and Obiora, 2014). Lichens colonize the dump fields first by retaining moisture and secreting specific acids which contribute to a rapid physical and chemical weathering of the substrate, thus preparing it for holding vascular plants (Lambion and Auquier, 1963; Banásová, 1985).

Slovakia is famous for its rich mining history, especially for copper mining, but also for mining of gold, silver and other minerals. The most famous mining district where copper was extracted was Banská Bystrica (Staré Hory Mountains, central Slovakia). We aim to link our research to the results of the long-term floristic research at one of the largest and longest active Slovak copper mine heaps Piesky, situated near the village Špania Dolina. We concentrate on the analysis of its floristic components in terms of species richness and diversity, using several indexes, including both traditional and newer approaches (Tuomisto, 2011). Furthermore we evaluated the proportions of metallophytes, invasive alien species, synanthrophytes and native non-apophytes in the vegetation on a heap. We also tried to contribute to elucidating a few ecological links, concerning numbers and proportions of the specific groups of species in the heap's flora and their relations to some climatic and edaphic variables. The basic hypothesis tested here emanates from the assumption that vegetation development during succession on any mine dump heap is strongly connected with the soil development. Then we expect that the numbers and relative abundances of metallophytes and synanthrophytes (and therefore also the degree of vegetation metallophytisation and synanthropisation) will decrease towards later (higher) successional stages, or at least will be lowest in a climax, while the trend of native apophytes representation will be in the opposite direction. We also expect that the species turnover between the sites belonging to the same type of habitat will decrease in the same direction. Finally, we add a few recommendations for managing the Piesky mine heap based on the results of our field surveys and statistical analysis, which reflect studies and proposals that have already been published (řehounková et al., 2011).

\section{Materials and methods}

\subsection{Study area}

The studied area belongs to the protective buffer zone of the Low Tatras National Park. For this area the occurrence of two dominant minerals of primary copper ores - tetrahedrite and chalcopyrite - is typical. According to the results of archaeological research, traces of copper ore mining date back to the early Neolithic Age (at the end of the 4th millennium BC). In the late Bronze Age, the territory of Špania Dolina was considered to be one of the most important copper deposits in Europe. Maximum development of copper ore mining with an extremely valuable silver content occurred during the years 1496-1546. In the 16th century a copper enterprise in Banská Bystrica (Thurzo-Fugger company), dependent mainly on this deposit, was the largest copper producer in the world. Since the 17th century, mining gradually declined until the early 20th century when it completely stopped (Jelen et al., 2009). In the 1950s-1980s the lower parts of the mine heap with higher copper content were exploited by surface mining (Mazúrek, 1989), but this was closed due to a lack of profitability. The copper content in the soil is very variable (from 100 to over $9000 \mathrm{ppm}$ ).

The dump field is located near the former mining village Piesky (formerly Sandberg) under the spot height Glezúr (968 m a.s.l.). Today they belong to the Špania Dolina cadaster (Fig. 1). There are large sloping surface dump heaps situated at an altitude of 739-873 m and their total length along the slope is $730 \mathrm{~m}$. The estimated actual cubature of this dump field is $267967 \mathrm{~m}^{3}$. Between the years 2000 and 2010, the dump field was recultivated. The recultivation included slope cascade and inclination adjustment, rainwater drain construction into a drainage pond and delivery of sewage sludge and soil on one part of the heap and its grassing (Klusová et al., 2009). 


\subsection{Field data sampling}

Floristic and vegetation research was carried out in 20112014. Phytosociological relevés were made using the extended Braun-Blanquet combined scale (Barkman et al., 1964) to capture the variability of represented plant communities. Phytosociological relevés were realized on each mine heap habitat regardless of the topographical (various slopeness, exposition and altitude) and ecological variability (moisture, content of nutrients), various successional stages (initial ones, higher stages with continuous grassland cover, the highest with forest stands) and human impact (input of water treatment plant sludge during the reclamation and the delivery of fodder for wild animals in one of the sites).

The eleven phytocenological relevés were differentiated in five habitats - wetland (phytocenological relevé/site 1), initial successional stages (sites 2-6), grassland (sites 7-8), forest stand (sites 9-10) and a feeding ground for wild animals (PWA, site 11). The number of relevés in each of these habitats depended on the estimatation of their area within the mine heap.

Plant nomenclature follows Marhold and Hindák (1998).

\subsection{Data analysis}

The alien taxa were classified into invasive, casually invasive and naturalized ones according to Medvecká et al. (2012). As naturalized taxa do not provide evidence of the natural or non-natural character of the community, we have taken into account just two first categories: invasive and casually invasive species. For the metallophytes, we consider both obligatory and facultative metallophytes according to Zarzycki et al. (2002).

To understand the abiotic characteristics of the mine heap, we determined the active and changeable $\mathrm{pH}$ according to the methodology of Sobek et al. (1978). On the whole surface of the heap, by stratified selection from beneath the plant roots, we took a total of 120 soil samples. The samples were divided into three composite samples at random, each of which were homogenized and analysed.

\subsubsection{Transformation of cover-abundance values, standard and true diversity indexes}

The transformation of the 9-graded Braun-Blanquet scale into a numerical one was done according to van der Maaler (2007), using the alternative approximation with a steeper scale. Apart from the most simple diversity index for species richness, so-called diversity of the order zero (Jost, 2006), we have also used alpha, gamma and beta diversity (more precisely alpha, gamma and beta species richness) related to individual habitats, considering three categories: all plant taxa, bryophytes and vascular plants. The beta diversity expresses the speed of the vegetation composition change between individual sites (Primack et al., 2011). In this way we tried to express the species turnover within initial successional stages

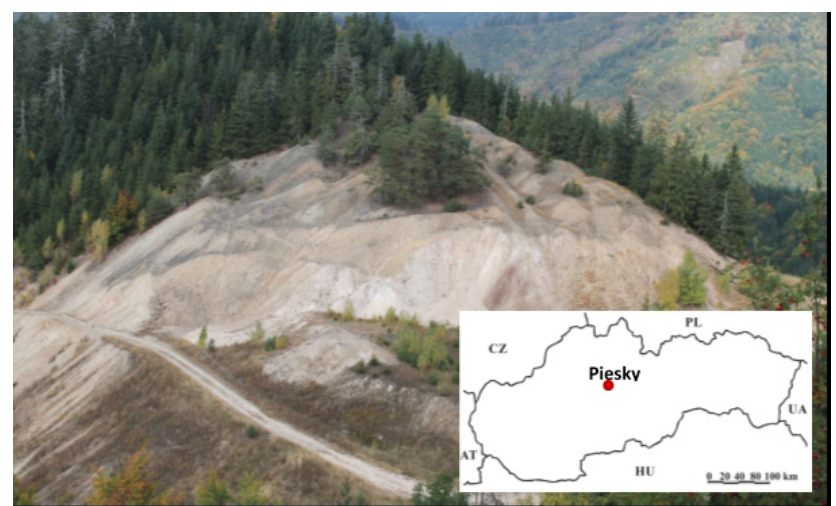

Figure 1. The studied area in the surroundings of Špania Dolina and Staré Hory (central Slovakia).

(sites 2-6), grasslands (sites 7-8) and forest stands (sites 910). (As here both wetland and PWA consist of just one site, their beta diversity is always 1 and thus meaningless).

The structure and complexity of the vegetation composition in each relevé, including diversity, was indicated via the Shannon-Wiener index (Shannon and Weaver, 1948; Eq. 1).

$$
\begin{aligned}
\mathrm{SW} & =-\sum_{i=1}^{S} p_{i} \cdot \ln \left(p_{i}\right) \\
& =-\sum_{i=1}^{S}\left(n_{i} / N\right) \cdot \ln \left(n_{i} / N\right),
\end{aligned}
$$

where $n_{i}$ is the abundance of the taxa $i$ in a given phytocenological relevé or site. Thus $p_{i}=n_{i} / N$ is the proportional (relative) abundance of the taxa $i$ in the community described in a given phytocenological relevé (from a given site). $S$ is the species richness, i.e. total number of taxa in a site and $N$ is the total sum of the abundances of all the $S$ taxa. As a complementary indicator we also used the traditional approach of Pielou's index of equitability (Pielou, 1975; Eq. 2):

$\mathrm{EQ}=\mathrm{SW} / \ln (S)=-\sum_{i=1}^{S} p_{i} \cdot \ln \left(p_{i}\right) / \ln (S)$

The Shannon-Wiener index is widely used, but also criticized because it denotes a particular case of entropy and not true diversity (Tuomisto, 2011). Therefore, we have used two other indexes based on the Hill numbers (Hill, 1973), which were into a great depth elaborated by Jost (2006), who described them just as special cases of a much more general form (Eq. 3):

${ }^{q} D=\left(\sum_{i=1}^{S} p_{i}^{q}\right)^{1 /(1-q)}=\left(\sum_{i=1}^{S}\left(n_{i} / N\right)^{q}\right)^{1 /(1-q)}$,

where $D$ is the effective number of species and $q$ denotes order of diversity. For $q=0,{ }^{0} D=S, S$ denotes species richness. For $q=1 D$ can be derived from the Shannon-Wiener index and for $q=2$ it can be derived from the Simpson index 
(Eqs. 4 and 5):

$$
\begin{aligned}
{ }^{1} D & =\exp \left[-\sum_{i=1}^{S} p_{i} \cdot \ln \left(p_{i}\right)\right] \\
& =\exp \left[-\sum_{i=1}^{S}\left(n_{i} / N\right) \cdot \ln \left(n_{i} / N\right)\right] \\
{ }^{2} D & =1 / \sum_{i=1}^{S} p_{i}^{2}=1 / \sum_{i=1}^{S} \cdot\left(n_{i} / N\right)^{2}
\end{aligned}
$$

According to Jost (2006) these indexes represent first order and second order "true diversity indexes". The adjective "true" here does not mean that other indexes are wrong, but that these new ones are better fitted to describe species diversity in a real world. According to Jost (2006) and Tuomisto (2011) also diversity orders should be distinguished. The most important ones are zero order diversity (equals to species richness), first order true diversity (in the Eq. (3) the parameter $q=1$, leading to Eq. 4) and second order true diversity (in the Eq. $3 q=2$, leading to Eq. 5). We prefer this terminology to the Hill numbers and we call ${ }^{1} D$ shortly as a first true diversity index and ${ }^{2} D$ as the second true diversity index. There exists also the zero order of true diversity index, which equals to species richness. Diversity on this level fully ignores species abundances. As the order of the true diversity indexes rises, the weight of species abundances rises (Tuomisto, 2011), therefore the arithmetic mean (Eq. 5) gives higher value to abundant species (in relation to rare ones) than the geometric mean (Eq. 4).

\subsubsection{Indexes of metallophytisation, invasive alien taxa proportion, synanthropisation, native non-apophytes proportion and naturalness}

In the age of the Anthropocene and its period of great acceleration of socio-economic development accompanied with analogic acceleration of earth-system degradation (Steffen et al., 2015), it is useful to have tools to measure the degree of this degradation such as distinctive features of vegetation. Changes in the vegetation composition (either in anthropogenically disturbed sites or in restored ones), especially the terms synanthropisation, nativeness and naturalness are used (̌̌ehačková et al., 2011), but they are seldom precisely measured. Inspired by the first more complex formula of vegetation synanthropisation proposed by Jurko (1990) we have tried to develop original indexes of metallophytisation, invasive alien taxa proportion, indexes of synanthropisation, native non-apophyte taxa proportion and naturalness (presented below). As the lists of metallophytes, invasive alien species and synanthrophytes in Slovakia are currently limited to vascular plants, the notions of metallophytisation, synanthropisation, naturalness and their indexes used in this text are relevant just for vascular plant communities. Although we have also determined bryophytes, these only enter calculations of diversity indexes.

Similarly to cases of diversity, any meaningful quantification of the specific property of a plant community (e.g. degree of metallophytisation, synanthropisation) requires con- sidering both species numbers and relative abundances in phytocenological relevés. However, contrary to the true diversity indexes (Jost, 2006; Tuomisto, 2011) it is not enough to deal with effective numbers of species. We should take into account both rare and dominant species, as well as different subcategories, which reflect different contributions of individual species to the distinctive properties of vegetation (e.g. metallophilous vs. metal-tolerant species, obligatory invasive vs. casually invasive, obligatory synanthropic vs. facultatively synanthropic) We have tried to discriminate between these subcategories by means of the mechanism of weighted average (projected into relative weighted abundance of species and their relative weighted numbers).

The presence of a relative proportion of metallophytes in the vegetation of a site (concerning both their abundance and number) is given a more appropriate new term, "metallophytisation". The metallophytisation index is calculated as a function of the arithmetic average of relative weighted abundance and relative weighted species richness of metallophilous and metal-tolerant taxa, and of their ratio to the species richness of a particular site (Eq. 6).

$$
\begin{aligned}
\mathrm{MET} & =\left\{\left[\sum_{i=1}^{M_{1}} \text { metal_obligatory }_{i}\right.\right. \\
& \left.+\sum_{j=1}^{M_{2}}\left(\text { metal_tolerant }_{j} \cdot w_{1}\right)\right] / N \\
& \left.+\left[M_{1}+\left(M_{2} \cdot w_{1}\right)\right] / S\right\} / 2,
\end{aligned}
$$

where metal_obligatory $i$ and metal_tolerant ${ }_{j}$ denote the abundances of the metallophilous and metal-tolerant species $i, j$, while $N$ is the total abundance of all taxa in a site; $M_{1}$ is the number of the obligatory and $M_{2}$ of the facultative metallophytes and $S$ is the total number of taxa, i.e. species richness of a site. The fact that metallophilous species contribute to metallophytisation without any doubt, but the contribution of the metal-tolerant species is lower, we have reflected in the weight $w_{1}$ (always less than 1 , here we set $w_{1}=1 / 2$ ), which means that metal-tolerant species are less significant indicators of any metal presence in a site. Consequently, the expression $\left(\left[\sum_{i=1}^{M_{1}}\right.\right.$ metal_obligatory $_{i}+\sum_{j=1}^{M_{2}}$ (metal_tolerant $_{j}$ $\left.\left.\left.\cdot w_{1}\right)\right] / N\right)$ denotes relative weighted abundance of these two groups metallophytes and $\left[M_{1}+\left(M_{2} \cdot w_{1}\right)\right] / S$ denotes their relative number. Here again we have used the weight $w_{1}$ to denote lower significance of metal-tolerant species in relation to metallophilous ones. (After testing several tentative formulas for this index calculation we have realized that we are closer to reality if both the abundances and numbers of individual species have the same weight.) In this first approach we consider that both relative abundance and relative number of species contribute to the respective specific properties with the same weight.

The index of invasive alien taxa was calculated in an analogical way, considering both obligatory invasive and casually invasive species. These were differentiated according to 
the national list of alien species (Medvecká et al., 2012), which includes two categories of invasive alien taxa and two categories for the naturalized alien taxa. Again, we have to cope with their different contributions by means of a lower weight of the second category (casually invasive). The index equation is as follows (Eq. 7):

$$
\begin{aligned}
\mathrm{ALI} & =\left\{\left[\sum_{i=1}^{A_{1}} \text { alien_obligatory_invasive }_{i}\right.\right. \\
& \left.+\sum_{j=1}^{A_{2}}\left(\text { alien_casually_invasive }_{j} \cdot w_{2}\right)\right] / N \\
& \left.+\left[A_{1}+\left(A_{2} \cdot w_{2}\right)\right] / S\right\} / 2,
\end{aligned}
$$

where the alien_obligatory_invasive ${ }_{i}$ and alien_ casually_ invasive $_{j}$ denote abundances of the strongly invasive and casually invasive alien species $i, j$, while $N$ denotes total abundance of all the taxa in a site, $A_{1}$ and $A_{2}$ are the numbers of the invasive alien taxa in each of these categories and $S$ is the species richness in a site. Again, the expression $\quad\left[\sum_{i=1}^{A_{1}}\right.$ alien_obligatory_invasive $i+\sum_{j=1}^{A_{2}}$ (alien_casually_invasive $\left.\left.{ }_{j} \cdot w_{2}\right)\right] / N$ denotes relative weighted abundance of invasive alien species and the expression $\left[A_{1}+\left(A_{2} \cdot w_{2}\right)\right] / S$ denotes their relative weighted number; both of which reflect the different threats of taxa to native species from these two different categories. The contribution of obligatory invasive species (or strongly invasive) is always expected to be maximal (therefore it is without weight or its weight is always 1), while the contribution of casually invasive taxa depends on circumstances. Therefore, this contribution should be lowered by the weight $w_{2}$ (here we have set $w_{2}=1 / 4$ ).

Concerning synanthrophytes, we have started from the study by Jurko (1990), which differentiates obligatory synanthropic species and those which naturally occur in some natural and semi-natural communities, but may also occur in the synanthropic ones. This second group we have called "facultative synanthrophytes". While the contribution of the taxa from the first group to overall synanthropisation is without any doubt (is a maximal one, its weight is always 1), in case of the second group it depends on circumstances. For each species in this group it should be decided whether it occurs in a given community more or less naturally or contributes to its synanthropisation. Thus we have divided the facultative synanthrophytes into two groups called "locally strong facultative synanthrophytes" and "locally weak facultative synanthrophytes". As this decision also includes a subjective factor, we have differentiated their contribution by the weights $w_{3}=7 / 8=0.875$ and $w_{4}=1 / 8=0.125$. The consequent equation of the calculation of the synanthropisation of the vegetation sampled in a relevé is analogic (Eq. 8):
$\mathrm{SYN}=\left\{\left[\sum_{i=1}^{Y_{1}}\right.\right.$ obligatory_synanthrophyte ${ }_{i}$

$+\sum_{j=1}^{Y_{2}}$ (locally_strong_facultative_synanthrophyte $\left.{ }_{j} \cdot w_{3}\right)$

$+\sum_{k=1}^{Y_{3}}\left(\right.$ locally_weak_facultative_synantrophyte $\left.\left.{ }_{k} \cdot w_{4}\right)\right]$

$\left./ N+\left[Y_{1}+\left(Y_{2} \cdot w_{3}\right)+\left(Y_{3} \cdot w_{4}\right)\right] / S\right\} / 2$,

where obligatory_synnanthrophyte ${ }_{i}$, strongly_ facultative_ synanthrophyte $_{j}$ and weakly_facultative_ synanthrophyte $r$ denote abundances of the obligatory and locally strong, as well as locally weak facultative synanthropic species $i, j$ and $k ; N$ denotes total abundance of all the taxa in a site; $Y_{1}, Y_{2}$ and $Y_{3}$ are the numbers of these respective taxa of synanthrophytes and $\mathrm{S}$ is the species richness of a site; weights $w_{3}$ and $w_{4}$ reflect the different contributions of species from the point of view of synanthrophization (in this case we have set $w_{3}=7 / 8$ and $w_{4}=1 / 8$, following expert consultations and after comparing tentative calculations with real observations).

Finally, we have defined a category of species close to original wilderness (or to a potential natural vegetation). This includes species which are neither alien nor synanthropic. We have called this new category "native non-apophytes", as their representation indicates the degree of the authentic naturalness (naturalness sensu stricto) of vegetation and of the respective sites and habitats. The index of native nonapophytes (i.e. their representation in vegetation of a site or habitat concerning both their relative abundance and number) can be calculated analogically and rather simply (Eq. 9):

$$
\begin{aligned}
\mathrm{NAT} & =\left[\sum_{i=1}^{N n S} \text { native_non_apophyte }_{i} / N\right. \\
& +N n S / S] / 2,
\end{aligned}
$$

where native_non-apophyte ${ }_{i}$ denotes abundance of a native species $i$ which is neither an alien species, nor an apophyte species; $N$ denotes total abundance of all taxa in a site; $N n S$ is the number of all native non-apophytes and $S$ is the species richness of a site. The inverse index 1-NAT reflects the distance of actual vegetation to its authentic natural state (e.g. defined by the potential natural vegetation), as it is formed strictly by native and non-apophyte species.

Apart from this index, which reflects the distance of a sampled vegetation from the ideal natural state (defined e.g by potential natural vegetation), we also consider the naturalness index of a studied vegetation as important and practical. In the case of derelict mine heaps we probably do not have much chance to achieve strictly native and non-apophyte communities. But it is meaningful to support the development of near-natural communities (Řehounková et al., 2011) and to develop measurements of them. We start from the assumption that not only native non-apophytes contribute to a naturalness of vegetation (naturalness sensu lato) at a given 
site, but to a smaller extent casually invasive and facultatively synanthropic taxa do too. The consequent naturalness index of vegetation is as follows (Eq. 10):

$\mathrm{NAT}=\left\{\left[\sum_{i=1}^{\mathrm{NnS}}\right.\right.$ native_non_apophyte $_{i}$

$+\sum_{j=1}^{\text {Ans }}$ alien_naturalized $_{j}$

$+\sum_{k=1}^{A_{2}}$ alien_casually_invasive ${ }_{k} \cdot$ AND

NOT $\left(\right.$ synanthrophyte $\left._{k}\right) \cdot\left(1-w_{2}\right)$

$+\sum_{r=1}^{Y_{2}}$ locally_strong_facultative_synanthrophyte ${ }_{r}$

$\cdot\left(1-w_{3}\right)+\sum_{s=1}^{Y_{3}}$ locally_weak_facultative_synanthrophyte ${ }_{s}$

$\left.\cdot\left(1-\mathrm{w}_{4}\right)\right] / N+\left[\mathrm{NnS}+\mathrm{AnS}+A_{2} \cdot\left(1-w_{2}\right)+Y_{2}\right.$

$\left.\left.\cdot\left(1-w_{3}\right)+Y_{3} \cdot\left(1-w_{4}\right)\right] / S\right\} / 2$.

The elements of this equation are already described above, apart from the $\sum_{j=1}^{A n S}$ alien_naturalized $j$ which represents a relative weighted abundance of naturalized alien taxa and AnS, which denotes a number of naturalized alien taxa and their arithmetic average again analogically represents their contribution to the index of naturalness of vegetation in a studied site or habitat. (This latest equation, (10), is in inverse relation to Eqs. (7), (8) and (9), and can therefore be derived from them).

To summarize our point of view, the high number and relative complexity of the indexes related to hemeroby vs. naturalness of vegetation reflect a complex multispectral approach based on a detailed classification of the individual categories of alien species and synanthrophytes in Slovakia (Jurko, 1990; Medvecká et al., 2012). When calculating the metallophytisation index, invasive alien taxa index, synanthropisation index, native non-apophytes index and naturalness index we have taken into account both their relative weighted abundance (related to a total abundance $N$ of all taxa) and their relative weighted numbers (related to the species richness $S$ of vascular plants - as just these are classified in detail, as is needed) of a phytocenological relevé taken from a given site. The values of these indexes are always between 0 and 1 , and due to a common approach, all these indexes are easily comparable as well as expressive. The difference between indexes of native non-apophytes and naturalness should be noted. While the first one is inverse to distance of actual vegetation towards its original wild nature referential state (naturalness sensu stricto), the second one denotes naturalness of actual species composition (naturalness sensu lato), which may include not only non-native apophytes but also casually invasive alien species, naturalized alien species, as well as facultative synathrophytes, which may be quite natural in a respective site.

\subsubsection{Ellenberg indicator values and statistical analysis}

To carry out an ecological analysis, apart from measuring topographic data (elevation, sloppiness and exposition) we have calculated Ellenberg indicator values (EIVs) for each site (Ellenberg et al., 1992). These include climatic variables (light, temperature, continentality) and edaphic ones (moisture, soil reaction and nutrient content), and their values span between the integers 1 and 9. The EIV values are based on phytoindication of the site physical and chemical characteristics, as this saves time and expenses. They were calculated as a weighted arithmetic mean for each EIV (Eq. 11):

$\mathrm{EIV}_{k}=\sum_{i=1}^{S_{k}} A_{k, i} \cdot E_{k, i} / \sum_{i=1}^{S_{k}} A_{k, i}$

where $k$ is the order of the EIV numbers (e.g. EIV $1=$ EIV for light, $\mathrm{EIV}_{2}=\mathrm{EIV}$ for temperature), $A_{k, i}$ is the abundance of the $i$ th taxa, for which there exists an $\mathrm{EIV}_{k}, S_{k}$ is the number of taxa with allocated value of $\operatorname{EIV}_{k}$ (EIV of the order $k$ ). It should be noted that only taxa which have been allocated the $E_{k, i}$ value enter the respective mean $\mathrm{EIV}_{k}$ calculation; others are excluded. We prefer this simple mean EIV calculations to the formula of a modified weighted mean of the EIVs used by Czarnecka and Chabudziński (2013), as their approach suppresses the contribution of species with low abundance in a site.

Concerning ecological relations, our hypothesis relates to possible associations between Ellenberg indicator values and other variables. We have used correlation coefficients (both the classic Pearson and the robust Spearman) to find significant dependencies. A Spearman correlation coefficient was used for the suppression of outlier influences and for possible nonlinear relationships. Meaningful significant correlations were depicted in usual scatter plots with regression line and corresponding $95 \%$ prediction limits. All statistical analyses and their graphical illustrations were done by means of the statistical software SPSS, version 19.

\section{Results}

Soil reaction is slightly acidic or neutral shown by active $\mathrm{pH}$ values in anthropogenic soils which ranged from 5.25 to 6.01 and exchangeable $\mathrm{pH}$ values which ranged from 5.70 to 6.08 . This may be affected by genesis of soil sampling sites (predominant necrotic plant material) as well as by recultivation.

A large part of the mine heap is desolate, especially in exposed and non-recultivated locations without any vascular plant cover and this situation sporadically leads to erosion. Despite this, a specific feature of the dump field Piesky compared to other mine heaps in the district is that it has the highest diversity of habitats and microsites with different characteristics of the physiotope, which has produced a variety of plant communities. We studied a total of 11 phytosociological relevés across this variability with the total of 114 determined taxa of non-vascular and vascular plants. Of the 
Table 1. Alpha, gamma and beta diversity on the order of species richness of the relevés classified according to successional stages.

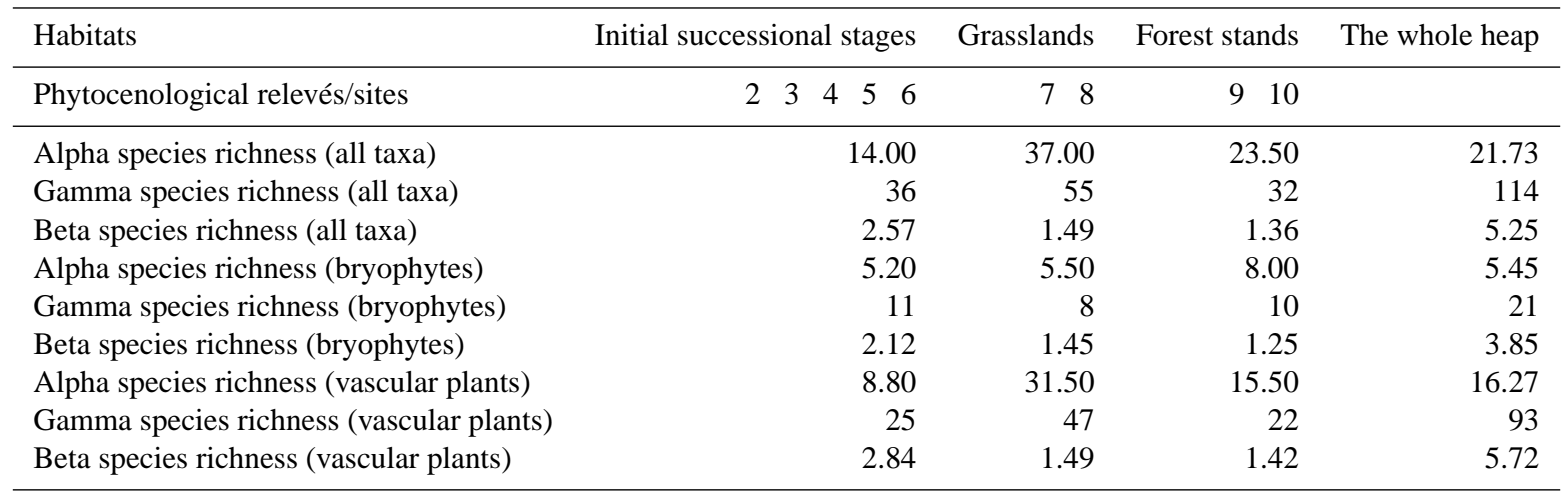

94 taxa of vascular plants, 11 are classified as metal-tolerant species, 13 are alien taxa and 52 are synanthropic and facultatively synanthropic.

The phytosociological relevés were classified into five habitats - initial successional stages, grasslands, forest stands, wetland and the place used for feeding of wild animals. We have found that wetland and grasslands have the highest species richness and also the highest numbers of metallophytic and synanthropic taxa (Figs. 2, 4). Despite the fact that number of phytocenological relevés was rather small, processing and analysis of the data obtained revealed a few tendencies concerning the representation of metallophytes, synanthrophytes versus the native and natural species on a heap.

In Table 1 we present the results from the calculations of alpha, gamma and beta diversity (on the level of species richness) for the three successional stages and for three groups of plants: bryophytes, vascular plants and all of the determined taxa. It can be seen that while both alpha and gamma diversity are highest in grasslands, the beta diversity decreases during succession (from initial successional stages through meadows towards the forest stands), reflecting more stabilized ecological conditions in higher stages. On the other hand, the high beta diversity of the whole mine heap (5.25) reflects highly variable ecological conditions on the heap and consequent mosaic character of the vegetation on its surface.

On older, pitched, strong skeletal but stable parts of the mine heap, stands of epilithic lichens and mosses are well developed, consisting mainly of Cladonia mitis (sites 3-4). On less pitched exposures, where at least a thin layer of soil developed in a rich cover of lichens and mosses, species such as Agrostis capillaris, A. stolonifera and Acetosella vulgaris have the highest abundances (sites 2, 5-6). On recultivated parts of the mine heap with a higher nutrient content a species-rich grassland vegetation of the Arrhenatherion elatioris W. Koch 1926 alliance with a predominance of Arrhenatherum elatius (locally Calamagrostis epigejos) and some ruderal, synanthropic and non-native species such as Artemisia vulgaris, Melilotus albus, Solidago canadensis and Tanacetum vulgare have developed (sites 7-8). The most advanced stage of succession is stands of trees dominated by the conifers Abies alba, Picea abies, Pinus sylvestris (sites 910) which are closer to suball. Eu-Vaccinio-Piceenion Oberd. 1957, according to their species composition.

At the bottom of the mine heap near the drainage pond, wetland communities occur with typical species such as Juncus inflexus, Mentha longifolia, Carex vesicaria, Lysimachia vulgaris and Rorippa palustris (site 1). It is the community with the highest plant diversity, including a relatively high proportion of metallophytes and synanthropic species. At the top of the mine heap in the vicinity of a hunting shed, two feeding grounds for wild animals are present, where corn cobs or oat are placed, gained mostly from the southern regions of Slovakia. Along with the food, seeds of other synanthropic and invasive species which have not been known so far in the wider surroundings of the study area, nor in the protection zone of the national park (e.g. Hibiscus trionum, Cannabis sativa) are also transported. The dominant species were Chenopodium spec. div., Echinochloa crus-galli and Datura stramonium (site 11).

From Fig. 2 it can be seen that the flora of the Piesky mine heap include a number of the synanthrophytes, relatively low numbers of metallophytes and just a few invasive alien species. A higher number of invasive taxa was found only at site 11 , where they have been brought together with the wild animal fodder. The highest numbers of synanthrophytes are in the nutrient-rich grasslands and in the wetland, which is supplied by nutrients washed from the upper parts of the heap. In accordance with recommendations of Tuomisto (2011) we have provided a larger diversity profile of the vegetation studied (Table 2). In case of more numerous vascular plant taxa (and of all the taxa) the statistical analysis confirmed a correlation between the Shannon-Wiener index and both first order and second order true diversity indexes. This means that even the widely used, but criticized ShannonWiener index is a useful indicator of diversity. The taxa diversity has been found to be highest in the grasslands and wetland, lower in the forest stands and mostly rather low 


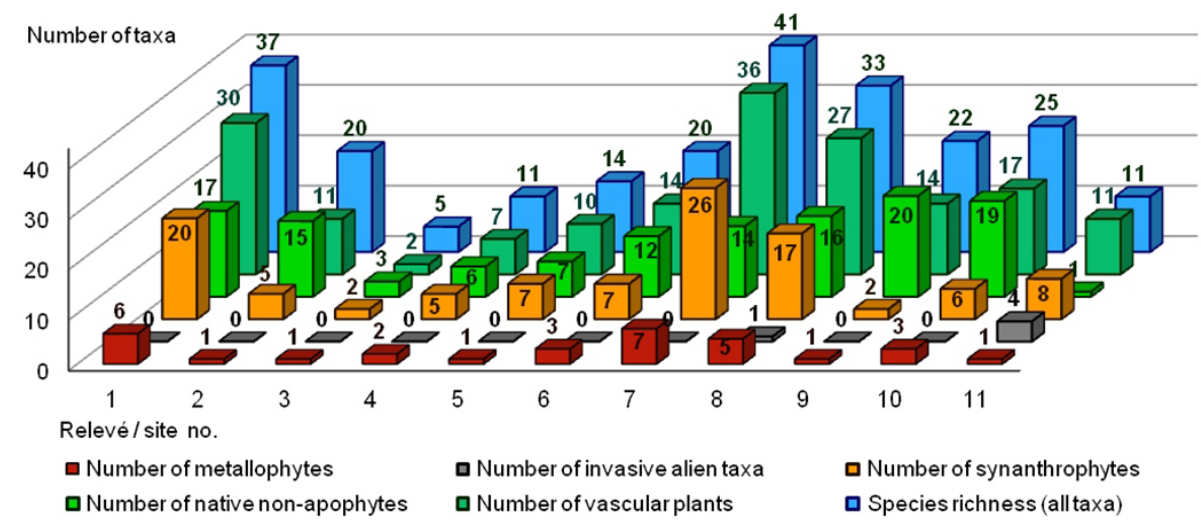

Figure 2. Numbers of the several types of determined taxa. The sites belong to these categories: wetland (site 1), initial successional stages (2-6), grasslands (7-8), forest stands (9-10), place for feeding wild animals (11).

Table 2. Several diversity indexes of vegetation sampled in the individual phytocenological relevés and calculated separately for the total taxa determined in the sites, bryophytes and vascular plants. (PWA is a place for feeding wild animals). The mean indexes of sites divided into five habitats are presented in a table in the Supplement.

\begin{tabular}{|c|c|c|c|c|c|c|c|c|c|c|c|}
\hline \multirow{2}{*}{$\begin{array}{l}\text { Habitats } \\
\text { Phytocenological relevés/sites }\end{array}$} & \multirow{2}{*}{ 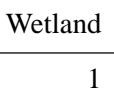 } & \multicolumn{5}{|c|}{ Initial successional stages } & \multicolumn{2}{|c|}{ Grasslands } & \multicolumn{2}{|c|}{ Forest stands } & \multirow{2}{*}{$\begin{array}{r}\text { PWA } \\
11\end{array}$} \\
\hline & & 2 & 3 & 4 & 5 & 6 & 7 & 8 & 9 & 10 & \\
\hline Shannon-Wiener diversity index (all taxa) & 2.85 & 1.70 & 1.08 & 2.09 & 2.14 & 2.09 & 2.87 & 2.64 & 2.32 & 2.39 & 1.47 \\
\hline Pielou's evenness index (all taxa) & 0.79 & 0.57 & 0.67 & 0.87 & 0.81 & 0.70 & 0.77 & 0.76 & 0.75 & 0.74 & 0.00 \\
\hline First true diversity index (all taxa) & 17.22 & 5.48 & 2.93 & 8.12 & 8.50 & 8.07 & 17.64 & 14.03 & 10.20 & 10.96 & 4.34 \\
\hline Second true diversity index (all taxa) & 3.21 & 1.64 & 1.50 & 2.58 & 2.32 & 2.21 & 2.95 & 2.97 & 2.40 & 2.62 & 1.66 \\
\hline Shannon-Wiener diversity index (bryophyt & 0.78 & 0.73 & 1.15 & 0.93 & 0.86 & 0.76 & 0.80 & 0.76 & 0.74 & 0.76 & 0.00 \\
\hline Pielou's evenness index (bryophytes) & 0.40 & 0.33 & 1.05 & 0.67 & 0.62 & 0.42 & 0.49 & 0.42 & 0.36 & 0.37 & 0.00 \\
\hline First true diversity index (bryophytes) & 2.18 & 2.09 & 3.16 & 2.54 & 2.37 & 2.14 & 2.22 & 2.14 & 2.11 & 2.14 & 1.00 \\
\hline Second true diversity index (bryophytes) & 1.98 & 2.29 & 1.32 & 1.61 & 1.94 & 2.31 & 2.18 & 2.31 & 2.21 & 2.00 & 0.00 \\
\hline Shannon-Wiener diversity index (vascular plants) & 2.59 & 0.75 & 0.50 & 1.60 & 1.77 & 1.76 & 2.68 & 2.45 & 1.70 & 1.95 & 1.47 \\
\hline Pielou's evenness index (vascular plants) & 0.76 & 0.31 & 0.72 & 0.82 & 0.77 & 0.67 & 0.75 & 0.74 & 0.64 & 0.69 & 0.01 \\
\hline First true diversity index (vascular plants) & 13.30 & 2.12 & 1.65 & 4.96 & 5.86 & 5.83 & 14.63 & 11.53 & 5.46 & 7.06 & 4.34 \\
\hline Second true diversity index (vascular plants) & 2.87 & 1.17 & 1.21 & 2.02 & 1.99 & 1.99 & 2.74 & 2.79 & 1.81 & 2.19 & 1.66 \\
\hline
\end{tabular}

and variable in the initial successional stages. The average indexes of metallophytisation are highest in the initial successional stages and decrease in latter ones, sharply dropping in the forest stands. This indicates that thicker layer of soil (in latter stages) provides a better buffer against negative impacts of anthropogenically disturbed substrate, especially concerning the presence of heavy metals inside the heap.

Due to both high abundance and high numbers of synanthrophytes in the studied flora (apart from the forest stands and a few initial successional stages) the indexes of synanthropisation are rather high according to expectations and highest at site 11 (devastated by the synergy of the fodder distribution and maybe also higher supply of wild animal excrements), but also in grasslands (supplied by nutrients from the water treatment plant) and in the wetland (situated at the foothill of the heap).

On the contrary, the index of native non-apophytes representation, as well as the index of vegetation naturalness are highest in the forest stands, where even the values of these two indexes are also much closer (Fig. 3). Average indexes measuring the specific vegetation properties on the level of the five distinguished habitats are presented in Table 3. It can be seen that, apart from the forest stands, the average value of the naturalness index is also relatively high in the initial successional stages (Fig. 4).

Ellenberg indicator values (Table 4) represent phytoindication of several physical and chemical properties of the sites. Note that each EIV fits into a linear $9^{\circ}$ scale, in which value 1 is the lowest and value 9 the highest. Therefore, EIV soil reaction scale is definitely different from the well-known logarithmic $\mathrm{pH}$ scale.

From the illustrations above it is clear that due to a small number of phytocenological relevés and other hidden factors, the variance of data is large. Despite this, the dependencies between selected variables of the numbers, relative abundances, anthropophytisation of the community and selected Ellenberg indicator values were found to be significant. In other words the correlation analysis has uncovered a number of significant associations between the various indicators of specific vegetation properties (the numbers of various types 
Table 3. Average diversity indexes of vegetation per individual habitats and calculated separately for the total taxa determined in the sites, bryophytes and vascular plants. (PWA is a place for feeding wild animals).

\begin{tabular}{|c|c|c|c|c|c|c|}
\hline Habitats & Wetland & Initial successional s & tages & Grasslands & Forest stands & PWA \\
\hline Phytocenological relevés/sites & 1 & 234 & 56 & 78 & 910 & 11 \\
\hline Average Shannon-Wiener index (all taxa) & 2.85 & & 1.82 & 2.76 & 2.36 & 1.47 \\
\hline Average evenness index (all taxa) & 0.79 & & 0.72 & 0.76 & 0.75 & 0.00 \\
\hline Average first true diversity index (all taxa) & 17.22 & & 6.62 & 15.84 & 10.58 & 4.34 \\
\hline Average true diversity index (all taxa) & 3.21 & & 1.64 & 2.95 & 2.40 & 1.66 \\
\hline Average Shannon-Wiener index (bryophytes) & 0.78 & & 0.89 & 0.78 & 0.75 & 0.00 \\
\hline Average evenness index (bryophytes) & 0.40 & & 0.62 & 0.46 & 0.36 & 0.00 \\
\hline Average first true diversity index (bryophytes) & 2.18 & & 2.46 & 2.18 & 2.12 & 1.00 \\
\hline Average second true diversity index (bryophytes) & 1.98 & & 2.29 & 2.18 & 2.21 & 0.00 \\
\hline Average Shannon-Wiener index (vascular plants) & 2.59 & & 1.28 & 2.56 & 1.83 & 1.47 \\
\hline Average evenness index (vascular plants) & 0.76 & & 0.31 & 0.75 & 0.64 & 0.01 \\
\hline Average first true diversity index (vascular plants) & 13.30 & & 2.12 & 14.63 & 5.46 & 4.34 \\
\hline Average second true diversity index (vascular plants) & 2.87 & & 1.17 & 2.74 & 1.81 & 1.66 \\
\hline
\end{tabular}

Table 4. Ellenberg indicator values for individual sites (PWA is a place for feeding wild animals, EIV is the Ellenberg indicator value). $\times$ means that there are no taxa in a site with the allocated respective EIV.

\begin{tabular}{|c|c|c|c|c|c|c|c|c|c|c|c|}
\hline Habitat & Wetland & \multicolumn{5}{|c|}{ Initial successional stages } & \multicolumn{2}{|c|}{ Grasslands } & \multicolumn{2}{|c|}{ Forest stands } & PWA \\
\hline Phytocenological relevés & 1 & 2 & 3 & 4 & 5 & 6 & 7 & 8 & 9 & 10 & 11 \\
\hline EIV - light & 6.79 & 6.90 & 7.20 & 7.24 & 6.86 & 7.78 & 7.39 & 7.46 & 4.39 & 4.83 & 7.68 \\
\hline EIV - temperature & 4.87 & 5.00 & $\mathrm{x}$ & 5.00 & 5.73 & 5.95 & 5.66 & 5.86 & 4.86 & 3.88 & 6.31 \\
\hline EIV - continentality & 3.53 & 3.07 & 3.00 & 4.23 & 3.08 & 3.67 & 3.60 & 3.68 & 4.31 & 4.88 & 5.01 \\
\hline EIV - moisture & 6.80 & 5.00 & $\mathrm{x}$ & 5.47 & 5.42 & 4.81 & 4.69 & 5.47 & 4.25 & 5.49 & 4.11 \\
\hline EIV - soil reaction & 6.57 & 3.96 & 3.40 & 3.37 & 4.23 & 5.41 & 5.47 & 5.87 & 2.24 & 2.56 & 7.04 \\
\hline EIV - nutrients & 5.12 & 4.20 & 3.60 & 5.55 & 5.42 & 4.45 & 5.18 & 5.28 & 2.83 & 3.58 & 7.18 \\
\hline
\end{tabular}

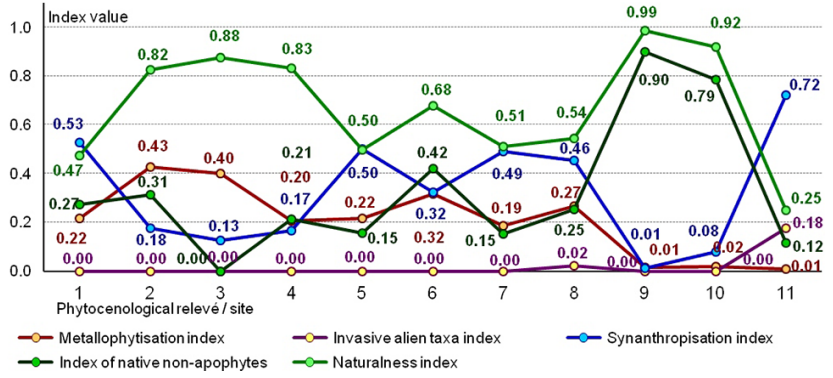

Figure 3. Indexes of metallophytisation, invasive alien taxa proportion, synanthropisation, non-native apophytes proportion and naturalness index.

of taxa, their relative abundances, indexes of metallophytisation, synanthropisation, invasive alien taxa vs. native nonapophytes representation and naturalness) on one hand and respective climatic and edaphic EIV variables on the other hand. From these we have selected the following as especially noteworthy:

1. A negative correlation exists between the number of native non-apophytes and temperature (Fig. 5a), and also between the average number of native non-apophytes and light (Fig. 5b). This explains why in this heap the number of native non-apophytes is the highest in the forest stands, while EIV light and EIV temperature are the lowest. It seems that more stabilized ecological conditions in the forest stands (compared to open habitats) allow more efficient autophytoremediation based on autoorganisation of the vegetation structure, which spontaneously develops to higher naturalness even on anthropic substrate.

2. A positive correlation exists between the synanthrophytisation index and the soil reaction (Fig. $5 \mathrm{c}$ ) and between this index and the nutrient content (Fig. 5d). The same type of correlation was also found between the average synanthropisation index of vegetation (per individual habitat) and soil reaction or nutrients. In the higher altitudes the natural content of nutrients is not high, therefore the native non-apophytes, which inhabit the mine heap from the nearby habitats, are mostly mesotrophic or oligotrophic. The high input of nutrients to sites 7-8 (grasslands), site 1 (wetland) and site 11 is responsible for the increase in the representation of synanthrophytes, which are mostly eutrophic species. 


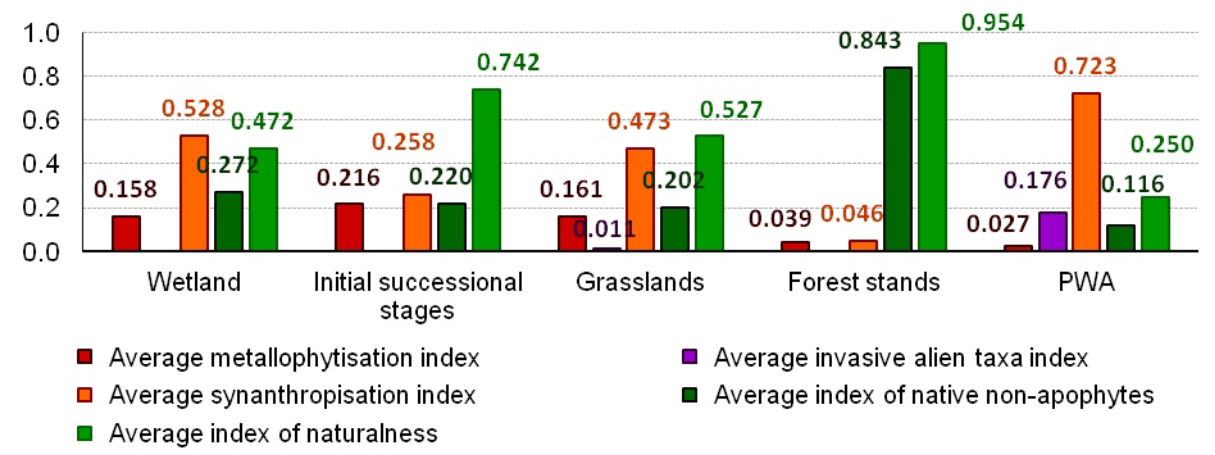

Figure 4. Average indexes of metallophytisation, invasive alien species, synanthropisation, non-native apophytes and naturalness index, according to individual habitats.

The flow of nutrients into these sites comes from the water treatment plant sludge applied during the reclamation process (sites 7-8), from the waters washing up the heap (site 1) and from delivery of the fodder for animals (site 11). A sharp retreat of synanthrophytes at sites 9 and 10 (forest stands) indicates that in higher successional stages, the synanthropisation is significantly lower. All of this partially confirms our hypotheses.

3. On the contrary (as can be expected), the naturalness index is negatively correlated with soil reaction (Fig. 5e) and nutrient content (Fig. 5f), and analogic negative correlations were found between native non-apophyte representations and soil reaction and nutrients. The explanation is the same as in point 2).

Concerning metallophytes, no meaningful correlation of their subgroup with EIV variables was found. Therefore, the part of our hypothesis concerning metallophytes is not confirmed. On the other hand, their relative abundance and metallophytisation index are the highest in the initial successional stages and lowest in case of the forest stands (Fig. 3).

\section{Discussion}

Research on the vegetation growing on mine heaps is rather important due to growing numbers and scale of anthropic metalliferous substrates and the necessity to help to speed up their decontamination by means of phytoremediation (Prasad and Freitas, 2003). The structure of vegetation growth under these conditions is essentially an indicator of soil development (Banásová, 1976). The vegetation is diverse even within one mine heap, depending on the conditions of microhabitats (terrain depression, mine heap margins, leaf litter availability etc.) and also on human interventions, particularly in the process of recultivation. This variability of microhabitats often leads to higher habitat and species diversity of these heaps (Ǩehounková et al., 2011) and thus also to the mosaic structure of their vegetation. This was also confirmed on the Piesky mine heap, where the zero order beta diversity of the whole heap is rather high $(\beta=5.25$ for all the taxa and $\beta=5.72$ for the vascular plants). On the contrary, the ecological conditions stabilize towards higher successional stages, which is indicated by the consequent decrease of this beta diversity (concerning all the taxa $\beta=2.57$ in the habitat of the initial successional stands, $\beta=1.49$ in the grasslands and $\beta=1.25$ in the forest stands).

Plants growing in such derelict habitats, are significantly different from their relatives growing in natural sites (Przedpelska and Wierzbicka, 2007). These taxa are often characterized by a high vitality which is a result of good adaptation mechanisms and an ability to eliminate nutritionally competitive but less adaptive species (Lambinon and Auquier, 1963). Their communities include a number of metallophytes, which we classified in our study as either obligatory metallophytes or facultative metallophytes (i.e. metal-tolerant or metallophytes sensu lato). In the Piesky mine heap just the metallophytes from the second category have been found. Although research of metallophytes has sped up, our knowledge of them and their capacity to accumulate metals is still rather small (Prasad, 2001). There are studies which consider other species as metallophytes, but without distinguishing between obligatory metallophytes or metal-tolerant species, e.g. several studies assign Acetosella vulgaris, Agrostis capillaris, Avenella flexuosa as being such species (cf. Banásová, 1983; Baker et al., 2000; Banásová and Hajdúk, 2006), as well as Arabidopsis arenosa (Banásová et al., 2006; Przedpelska and Wierzbicka, 2007; Čiamporová et al., 2009). For species Silene dioica and Agrostis capillaris it has been experimentally shown that they occur normally on substrates rich in heavy metals, and are able to create tolerant ecotypes (Ernst, 1974; Verkleij and Prast, 1989; Ernst et al., 1992). Metal-tolerant species are known from other mine heaps - Anagalis arvensis, Echium vulgare, Plantago lanceolata, Poa annиa, Rubus caesius from Hungarian Gyöngyösoroszi (Tamás and Kovács, 2005); Juncus conglomeratus, Juncus effusus, Scripus holoschoenus from Portuguese Sao Domingos (Frietas et al., 2004); taxa Mielichhoferia spp., Pohlia drummondi, Silene vulgaris and 

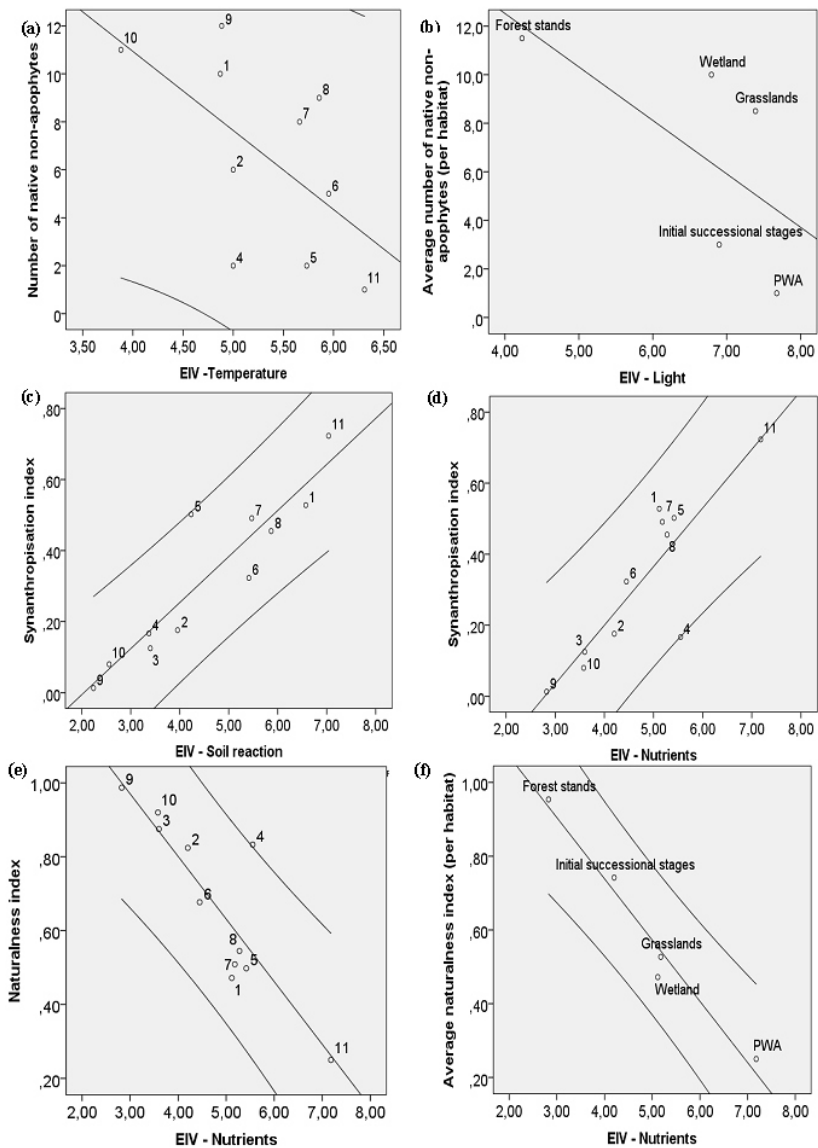

Figure 5. Scatter plots of the selected correlation associations between selected numbers of species, indexes of synanthropisation, naturalness and certain Ellenberg indicator values. Panels (a), (c), (d) and (e) illustrate correlations within the relevés framework and panels (b) and (f) illustrate correlations within the habitats framework.

Saxifraga stellaris from Salzburg in Austria (Adlassing et al., 2012); Agrostis capillaris and Festuca rubra from Burn of Sorrow in Scotland (Thompson and Proctor, 1983). A study of metallophytic vegetation in central Europe is summed up in a work by Baumbach (2012). As dominant species he ranks Arabidopsis spp., Armeria maritima, Minuaria verna, Silene vulgaris, Thlaspi caerulescens and Viola calaminaria. Another important piece of research on the flora of the disturbed and mining sites in the central Europe, especially in the Czech Republic, is represented by the robust studies of Prach et al. (2014) and Řehounková et al. (2011), who also provide important insights concerning the advantages of the spontaneous succession and requirements of the near-natural restoration of such sites.

On the Piesky mine heap, a total of 156 taxa of vascular plants was recorded (Turisová et al., 2014), in which acidophilous and metal-tolerant species such as Acetosella vulgaris, Agrostis capillaris, A. stolonifera, Arabidopsis arenosa, Festuca rubra and F. pratensis dominated. Agrostis capillaris often grew as the only vascular plant between the islet sites with lichens and bryophytes. A more detailed floristic study of the $\mathrm{Cu}$-mine heap Maximilián from the same mining district was published by Aschenbrenner et al. (2011). The vegetation composition on the Piesky mine heap in the framework of the study of mine heap vegetation of Slovakia was partially captured in two phytosociological relevés by Banásová (1976), which she added to the newly described ass. Cladonio (mitis)-Silenetum (inflatae) Banásová (1976) representing the initial stages of natural succession on $\mathrm{Cu}$-mine heaps. Currently they are abundant due to very slow succession. This part of vegetation cover on the Piesky mine heap is represented by the phytocenological relevés from sites 3 and 4 . However, neither of the previous studies characterized the mine heaps by means of the metallophytisiation index. Its use in our study illustrates that this index on the average decreases in the direction from the initial successional stages towards higher stages (although, due to low number of metallophytes, this was not confirmed as a statistically important trend).

It is also noteworthy that despite more than one hundred years of the heap existence, the invasive alien taxa are mostly absent. The exceptions are sites 7 and 11, where the diaspores of invasive species could be brought by dump sludge or fodder.

When trying to assess the role of specific taxa on a mine heap we have encountered a lack of a consistent terminology. Therefore we introduce a new term "metallophytisation", as a quantitative measure of the metallophytes participation in vegetation structure, introducing also an original index to calculate this measure. A discussion of the terms "invasiveness" and "nativeness" would interesting. For example Trigger et al. (2008) use the term "naturalness" as a synonym for "nativeness", and Machado (2004) considers the native system ("natural virgin system") to mean the highest degree of naturalness. To our understanding the above terms are different: naturalness indicates the degree of the natural composition of the vegetation in a site (which may include naturalized alien species or even facultatively synanthropic taxa), while nativeness expresses the degree to which this composition is close to the original native vegetation before the anthropogenic changes of a respective site had begun. We respect the ongoing discussion on terminology and we have used the term "native non-apophytes index", not "nativeness index". In Fig. 3 it can be seen that the values of the naturalness index and index of native non-apophytes differ mostly in the early successional stages (sites 3-4,2) and little in the close to climax stage (sites 9-10).

Concerning the evaluation of vegetation ecological status, a number of approaches is based on qualitatively differentiated categories of naturalness (e.g. 11 categories defined by Machado, 2004). The studies on quantitative indexes of vegetation naturalness or its opposite, hemeroby, are rarer and still in development. Ciecierska and Kolanda (2014) present a synanthropisation index as a part of the 
larger macrophyte index for assessing the ecological status of lakes. However, their index is based on "the degree of simplification of the taxonomic composition and spatial structure of biotic communities resulting from anthropogenic pressure" and is expressed by means of the colonization index $Z$ based on sizes of qualitatively different areas. Serafin and Pogorlezec (2011) calculate the synanthropisation index as a relative number of synanthrophytes in the list of flora in respective sites (Eq. 12):

Total synanthropisation $=W_{S-c}=\left(A_{p}+A\right) /\left(S_{p}+A\right)$,

where $A_{p}$ and $A$ are the numbers of apophytes and anthropophytes and $S_{p}$ is the number of spontanneophytes + apophytes. It is correct to use this simplified index to evaluate the anthropogenic changes of flora, but not vegetation. A similar approach was taken by Myśliwy (2008) who estimated synanthropisation of the forest flora on the basis of representation of individual groups of species (in \%) in the flora determined along the section of the surveyed forest dividing lines. In Slovakia, vegetation analyses and evaluations of its ecological significance (e.g. Kostúrová and Diviaková, 2012) often start from the unique study by Jurko (1990), which calculates anthropophytisation $(A)$ and diversity and complexity of anthropophytes $\left(I_{A_{p}}\right)$ as follows (Eq. 13; Eq. 14):

$A=\left(A_{p} \cdot N_{A_{p}}\right) / 100$

$I_{A_{p}}=\left(A_{p} \cdot N_{A_{p}}\right) \cdot 100 \% /(S \cdot N)$,

where $A_{p}$ is the number of anthropophytes, $N_{A_{p}}$ is the total abundance of all the anthropophytes, $S$ is the total number of species and $N$ is the total abundance of all the taxa (note that in this formula we have used the symbols compatible to our formulae presented above). However, Eq. (13) is incorrectly called a degree of anthropophytisation as it does not include $S$ and $N$, which would enable it to calculate the relative representation of anthropophytes, concerning both their numbers and total abundance. A more correct approach is used in the case of Eq. (14), but this again leads to incorrect results. If, for example, $A_{p} / S=0.3$ and $N_{A_{p}} / N=0.7$ hold, our formula (analogic to Eq. 8) would result in their arithmetic average: $I_{A_{p}}=0.5$, while Eq. (14) would result in $I_{A_{p}}=0.21$, which severely underestimates the real anthropophytisation.

A complex study is presented by Kanka (2014), which includes a more detailed classification of synanthrophytes than ours, but synanthropisation is based only on the representation of various species types (in \%) in the flora of the sites.

Concerning calculations of the average Ellenberg indicator values for each site, Schaffers and Sýkora (2000) underline the necessity of calibrating these numbers in accordance with regional conditions. They studied the reliability of these indicators for moisture, soil reaction and nutrients. Closer coincidences have been found when the mean weighted EIVs were calculated on the basis of species abundances in the relevés. Our calculations are fully in accordance with their findings.

Despite the fact that our correlation analysis was limited to a small number of samples, several important dependencies between the flora composition and the EIV have been confirmed. On the heap Piesky the synanthrophytes numbers and abundances sharply drop in high successional stages, closer to climax (forest stands), which is at least partially confirmed by the significant negative correlation between the native non-apophytes numbers and the EIVs of temperature and light. The retreat of synathrophytes and renewal of a near-natural character in part of this mine heap was probably supported by the surrounding relatively natural forests.

The analysis of vegetation development on the Piesky mine heap indicates that even in such sites the return of the near-natural climax vegetation is possible (represented here by the forest stands with a lower canopy closure). However, the speed of succession on this toxic mine heap is slower than on other types of derelict sites and it definitely takes longer than the 20-25 years mentioned as the renewal interval of derelict sites in the literature (Řehounková et al., 2011). It is also noteworthy that despite more than one hundred years of the heap Piesky existence, the invasive alien taxa are mostly absent. The exceptions are sites 7 and 11, where the diaspores of invasive species could be brought by the dump sludge from the water treatment plant or by the animal fodder. Despite the limited extent of our study, the above mentioned findings are in line with those of a systematic robust research of disturbed sites in the Czech Republic by Prach et al. (2014).

The indexes we have proposed for the calculation of metallophytisation, invasive alien taxa proportion, synanthropisation, native non-apophytes proportion and naturalness need further tuning, especially concerning the weights allocated to the specific groups of taxa, and maybe a more detailed classification of the types of taxa entering the proposed formula is also needed. Despite this we believe that the need for this kind of aggregated indexes is obvious. Furthermore, it is important to develop these indexes in an analogical way, which makes them systematic and allows for cross-verification of the calculated values.

\section{Conclusions}

The dump field Piesky represents a specific environment for plant growth and development. This environment is significantly affected by recultivating the mine heap body and creating conditions for the development of a varied vegetation cover. On the mine heaps at Piesky there are also sites not affected by recultivation (especially on the top part), providing a good picture of the vegetation without human intervention, be it the initial stages of vegetation or secondary mixed woodland. The actual management of the mine heap body provides a good space for a long-term comparison of the composition and evolution of vegetation in areas with natu- 
ral primary succession and recultivated areas. We summarize that as mine heaps are extreme habitats, even a small ecological study may bring new insights, or highlight the results of much more robust studies.

Concerning the results obtained, for future management of the Piesky mine heap and similar mine heaps we recommend a few measures:

1. The succession process even on toxic mine heaps may lead to re-establishment of near-natural vegetation. This is illustrated by the high values of the naturalness and native non-apophyte indexes which indicate species presence in the vegetation of the forest stands (sites 910). However, to achieve this goal it is necessary to prefer spontaneous succession processes (Řehounková et al., 2011), which require more time and hold off severe anthropic interventions.

2. In case of toxic mine dump heaps, it may be desirable to speed up the succession by human intervention, especially by supporting the soil development. The thicker soil layer provides a better buffer against toxic minerals in the heap and allows more biomass to grow. More nutrients in the soil mean more energy, which can speed up vegetation development. The higher amount of biomass accumulates even more of the available energy in an ecosystem (due to photosynthesis). According to the findings of non-equilibrium thermodynamics, the higher the amount of biomass, the greater its energy support for the development of more complex dissipative structures; simply to say, biomass accumulation serves as a fuel for switches to further successional stages within the autocatalytic network of succession process (Würtz and Anilla, 2010; Sabo et al., 2011).

3. However, the combination of derelict sites and too much free available energy also attracts opportunistic synanthropic species, which increases the species diversity but decreases the naturalness of vegetation (as illustrated by sites 7 and 8 ), as was confirmed also by the statistical analysis of the data from the Piesky mine heap. Therefore, it is necessary to avoid such interventions, which either increase toxicity of the heap or lead to its eutrophication. This also means that the goal of the near-natural renewal of these sites should not be to achieve a maximal plant taxa diversity, but an optimal one, naturally appropriate for a given locality, concerning the available free energy and other ecological conditions.

\section{The Supplement related to this article is available online at doi:10.5194/we-16-97-2016-supplement.}

Acknowledgements. The work was supported by the Scientific Grant Agency (VEGA 2/0099/13, VEGA 1/0255/14, VEGA 1/0538/15). We thank Štefan Aschenbrenner for his cooperation in field work. The authors are deeply grateful to three anonymous reviewers for their criticism and valuable comments on an earlier version of the manuscript.

Edited by: J. M. Halley

\section{References}

Adlassing, W., Wernitznig, S., and Lichtscheidl, I. K.: Historic copper spoil heaps in Salzburg (Austria): geology, mining history, aspect of soil, chemistry and vegetation, Soil Biol., 31, 201-231, 2012.

Aschenbrenner, Š., Turisová, I., and Štrba, T.: Flóra a vegetácia haldového pol'a v Španej Doline, Acta Univ. Matthiae Belii, ser. Environmentálne manažérstvo, 12, 48-57, 2011.

Baker, A. J. M., McGrath, S. P., Reeves, R. D., and Smith, J. A.: Metal hyperaccumulator plants: a review of the ecology and physiology of a biochemical resource for phytoremediation of metal-polluted soils, in: Phytoremediation of contaminated soils and water, edited by: Terry, N. and Banuelos, G., Lewis Publishers, Boca Raton, USA, 85-109, 2000.

Banásová, V.: Vegetácia medených a antimónových háld, Biologické práce, 22, 1-109, 1976.

Banásová, V.: Die Vegetation auf Pyrithalden und der Gehalt an $\mathrm{Cu}$, $\mathrm{Pb}, \mathrm{Zn}, \mathrm{As}, \mathrm{Ag}, \mathrm{Fe}$ und $\mathrm{S}$ in den Pflanzen und im Boden, Biológia, 38, 469-480, 1983.

Banásová, V.: Der Eifluss der Auftausalze auf Boden und Pflanzen an der Autobahn, Ekologia, 4, 315-328, 1985.

Banásová, V. and Hajdúk, J.: Príspevok k vegetácii banských háld z malokarpatských rudných ložísk, Bull. Slov. Bot. Spoločn., 28, 203-210, 2006.

Banásová, V., Horak, O., Čiamporová, M., Nadubinská, M., and Lichtscheidl, I.: The vegetation of metalliferous and nonmetalliferous grasslands in two former mine regions in central Slovakia, Biologia, 61, 433-439, 2006.

Barkman, J. J., Doing, H., and Segal, S.: Kritische Bemerkungenund Vorschlage quantitativen Vegetationanalyse, Acta Bot. Neerl., 13, 394-419, 1964.

Baumbach, H.: Metallophytes and metallicolous vegetation: Evolucionary aspects, taxonomic changes and conservational status in central Europe, in: Perspectives on natural conservation - patterns, pressures and prospects, edited by: Tiefenbacher, J., InTech, Rijeka, Croatia, 93-117, 2012.

Čiamporová, M., Staňová, A., Valaseková, E., Nadubinská, M., and Banásová, V.: Root anatomy and growth of three Arabidopsis species differing in their heavy metal tolerance, International symposium Root research and applications - RootRAP, Boku Vienna, Austria, 2-4 September 2009, 2009.

Chibuike, G. and Obiora, S.: Heavy Metal Polluted Soils: Effect on Plants and Bioremediation Methods, Appl. Environ. Soil Sci., 2014, doi:10.1155/2014/752708, 2014.

Ciecierska, H. and Kolada, A.: ESMI: a macrophyte index for assessing the ecological status of lakes, Environ. Minit. Assess. 186, 5501-5517, 2014.

Conesa, M. H., Faz, Á., and Arnaldos, R.: Heavy metal accumulation and tolerance in plants from mine tailings of the semiarid 
Cartagena - La Unión mining district (SE Spain), Sci. Total Environ., 366, 1-11, 2006.

Czarnecka B. and Chabudziński, L.: Asessment of flora diversity in a minor river valley using ecological indicator values, Geopgraphical Information Systems and Digital Elelvation Models, Centr. Eur. J. Biol., 9, 220-231, 2013.

Ellenberg, H., Weber, H. E., Düll, R., Wirth, V., Werner, W., and Paulissen, D.: Zeigerwerte von Pflanzen in Mitteleuropa, ed. 2, Scr. Geobot., 18, 1-258, 1992.

Emamverdian, A., Ding, Y., Mokhberdoran, F., and Xie, Y.: Heavy Metal Stress and Some Mechanisms of Plant Defense Response, The Scientific World Journal, 2015, doi:10.1155/2015/756120, 2015.

Ernst, W. H. O.: Schwermetallvegetation der Erde, Gustav Fischer Verl., Stuttgart, Germany, 1974.

Ernst, W. H. O., Verkleij, J. A. C., and Schat, H.: Metal tolerance in plants, Acta Bot. Neerl., 41, 229-248, 1992.

Frietas, H., Prasad, M. N. V., and Pratas, J.: Plant community tolerant to trace elements growing on the degraded soil of Sao Domingos mine in the south east of Portugal: environmental implications, Environ. Int., 30, 65-72, 2004.

Hill, M. O.: Diversity and evenness: a unifying notation and its consequences, Ecology, 54, 427-432, 1973.

Jeleň, S., Galvánek, J., Andráš, P., Bendík, A., Beláček, B., Bozalková, I., Gaál, Ĺ., Gajdoš, A., Háber, M., Konečný, V., Križáni, I., Luptáková, J., Mazúrek, J., Michal, P., Soták, J., Staňová, S., Šimo, V., Šurka, J., and Wetter, R.: Náučno-poznávací sprievodca po geologických a geografických lokalitách stredného Slovenska, Geologický ústav SAV, Banská Bystrica, Slovakia, 2009.

Jost, L.: Entropy and diversity, Oikos, 113, 363-375, 2006.

Jurko, A.: Ekologické a socioekonomické hodnotenie vegetácie, Príroda, Bratislava, Slovakia, 1990.

Kanka, R.: Diversity and selected functional traits of vascular plants on historical structure of agricultural landscape in south-western Slovakia, Actions for Wild Plants: Papers of the 6th Planta Europa, Conference on the Conservation of Plants, Polish Academy of Sciences, Kraków, Poland, 23-27 May 2011, 79-89, 2014.

Klusová, J., Hlaváč, I., and Danko, M.: Rekultivačný projekt Špania Dolina - Piesky, Report - Msc., Rudné Bane, Banská Bystrica, Slovakia, 2009.

Kostúrová, E. and Diviaková, A.: Hodnotenie významnosti nelesnej drevinovej vegetácie pre návrhy územného systému ekologickej stability (modelové územie: kataster obce Brusno), Acta Facultatis Ecologiae, 26, 21-26, 2012.

Lambion, J. and Auquier, P.: La flore et la végétation des terraine calaminaires de la wallonie septentrionale et de la Rhénnanio arxoist, Natura Mosana, 16, 113-130, 1963.

Machado, A.: An index of naturalness, J. Nat. Conserv., 12, 95-110, 2004.

Marhold, K. and Hindák, F. (Eds.): Zoznam nižších a vyšších rastlín Slovenska, Veda, Bratislava, Slovakia, 1998.

Mazúrek, J.: Ťažobný prírodno-technický systém v banskej oblasti Špania Dolina - Staré Hory, Stredné Slovensko, prírodné vedy, 8, 23-68, 1989.

Medvecká, J., Kliment, J., Májeková, J., Hal'ada, L', Zaliberová, M., Gojdičová, E., Feráková, V., and Jarolímek, I.: Inventory of the alien flora of Slovakia, Preslia, 84, 257-309, 2012.
Myśliwy, M.: Vascular plants of forest dividing-lines analyzed in respect of forest complex synanthropisation, Biodiv. Res. Conserv., 9-10, 63-72, 2008.

Pielou, E. C.: Ecological Diversity, John Wiley \& Sons, New York, USA, 1975.

Prach, K., Řehounková, K., Lencová, K., Jírová, A., Konvalinková, P., Mudrák, O., Študent, V., Vaněček, Z., Tichý, L., Petř́k, P., Šmilauer, P., and Pyšek, P.: Vegetation succession in restoration of disturbed sites in Central Europe: the direction of succession and species richness across 19 seres, Appl. Veg. Sci., 17, 193200, 2014.

Prasad, M. N. V.: Metals in the Environment, Analysis by Biodiversity, Marcel Dekker Inc., New York, USA, 2001.

Prasad, M. N. V. and Freitas, H. M. O.: Metal hyperaccumulation in plants - Biodiversity prospecting for phytoremediation technology, Electron. J. Biotechn., 6, 285-321, 2003.

Primack, R. B., Kindlmann, P., and Jersáková, J.: Úvod do biologie ochrany přírody, Portál, Praha, Czech Republic, 2011.

Przedpelska, E. and Wierzbicka, M.: Arabidopsis arenosa (Brassicaceae) from a lead-zinc waste heap in southern Poland - a plant with high tolerance to heavy metals, Plant Soil, 299, 43-53, 2007.

Řehounková, K., Řehounek, J., and Prach, K. (Eds.): Near-natural restoration vs technical reclamation of mining sites in the Czech Republic, Faculty of Sciences, University of South Bohemia, České Budějovice, Czech Republic, 111 pp., 2011.

Sabo, P., Uhliarová, E., and Turisová, I.: Koncepcie ekologickej komplexity a integrity a možnosti ich využitia pri výskume ekosystémov Slovenského krasu, in: Dynamika sukcesných procesov, štruktúry a ekologickej integrity ekosystémov Slovenského krasu, edited by: Vološčuk, I., 191-214, 2011.

Schaffers, A. P. and Sýkora, K. V.: Reliability of Ellenberg indicator values of moisture, nitrogen and soil reaction: a comparision with field measurements, J. Veg. Sci. 11, 225-244, 2000.

Serafín, A. and Pogorlezec, M.: Changes in the flora of the eastern and southern shore area of lake Piaseczno in the years 20032010, Acta Agrobot., 64, 141-150, 2011.

Shannon, C. E. and Weaver, W.: A mathematical theory of communication, Bell Syst. Tech. J., 27, 379-423 and 623-656, 1948.

Sobek, A. A., Schuller, W. A., Freeman, J. R., and Smith, R. M.: Field and laboratory methods applicable to overburden and minesoils, U.S. Environmental Protection Agency, Environmental Protection Technology, EPA 600/2-78-054, Cincinnati, USA, 1978.

Steffen, W., Broadgate, W., Deutsch, L., Gaffney, O., and Ludwig, C.: The trajectory of the Anthropocene: The Great Acceleration, The Anthropocene Review, 2, 81-98, doi:10.1177/2053019614564785, 2015.

Tamás, J. and Kovács, E.: Vegetation pattern and heavy metal accumulation at a mine tailing at Gyöngyösoroszi, Hungary, J. Biosci., 60, 362-367, 2005.

Thompson, J. and Proctor, J.: Vegetation and soil factors on a heavy metal mine spoil heap, New Phytol., 94, 297-308, 1983.

Trigger, D., Mulcock, J., Gaynor, A., and Toussaint, Y.: Ecological restoration, cultural preferences and the negotiation of 'nativenes' in Australia, Geoforum, 39, 1273-1283, 2008.

Turisová, I., Štrba, T., Andráš, P., and Aschenbrenner, Š.: Floristic composition on the abandoned copper heaps in Central Slovakia, Romanian Journal of Mineral Deposits, 87, 61-64, 2014. 
Tuomisto, H.: Commentary: do we have a consistent terminology for species diversity? Yes, if we choose to use it, Oecologia, 167, 903-911, 2011.

Van der Maarel, E.: Transformation of cover-abundance values for appropriate numerical treatment - Alternatives to the proposals by Podani, J. Veg. Sci., 18, 767-770, 2007.

Verkleij, J. A. C. and Prast, J. E.: Cadmium tolerance and cotolerance in Silene vulgaris (Moench.) Garcke $[=S$. cucubalus (L.) Wib.], New Phytol., 111, 637-645, 1989.
Würtz, P. and Anilla, A.: Ecological succession as an energy dispersal process, Biosystems, 100, 70-78, 2010.

Zarzycki, K., Trzcińska-Tacik, H., Rożański, W., Szeląg, Z., Wołek, J., and Korzeniak, U.: Ecological indicator values of vascular plants of Poland, W. Szafer Institute of Botany, Polish Academy of Sciences, Kraków, Poland, 2002. 